\title{
Unravelling the Bioherbicidal Potential of Eucalyptus Species Aqueous Leaf Extract and Leaf Oil on Germination and Initial Growth Performance of Weed Parthenium hysterophorus
}

\author{
Neeraj Prajapati ${ }^{1}$, Rupali Sharma ${ }^{2}$ and Hukum Singh ${ }^{1 *}$ \\ ${ }^{1}$ Silviculture and Forest Management Division, Forest Research Institute, \\ P.O. New Forest - Dehradun, 248006 (Uttarakhand) India \\ ${ }^{2}$ Department of Protected Area Network, Wildlife Management and Conservation Education, \\ Wildlife Institute of India, Dehradun, 248002 (Uttarakhand), India \\ *Corresponding author
}

\section{A B S T R A C T}

Trees, especially fast-growing multipurpose species, are becoming an integral part of intensive commercial agroforestry models introduced in recent times. Yet, the major hindrance for their productivity and survival is weed infestation with its toxic effects. They

\section{Keywords}

Phyototoxicity,

Biodiversity,

Parthenium,

Eucalyptus

\section{Article Info}

Accepted:

20 August 2020

Available Online:

10 September 2020 eventually decline the biodiversity by smothering native plants and disturbing their ecological niche. Parthenium hysterophorus invasion is a worldwide threat and acts as a potential menace in the biological phenomenons of germination and growth, effecting plant biodiversity. Our study aimed to examine the outcome of aqueous leaf extract (ALE) and leaf oil (LO) of three exotic Eucalyptus species (E. citriodora, E. tereticornis, and E. camaldulensis) on germination and growth performance of Parthenium hysterophorus using two experiments. In the first experiment, we compared the inhibitory effect of aqueous leaf extract and leaf oil on seed germination of weed, while in the second experiment, we studied the different concentrations of aqueous leaf extract and leaf oil of promising Eucalyptus species from the first experiment on Parthenium hysterophorus. We measured the growth characteristics such as Germination percent, Speed of germination, Root length, Shoot length, Total seedling length, Seed vigor, and Phytotoxicity percent. The study highlights species E. citriodora found to be more promising for weed control and subsequently selected using different concentrations for the second experiment. Bioassay of E. citriodora oil at $5 \mathrm{ppm}$ concentration was found to be more effective for weed suppression than aqueous extract concentrations. The study suggests an eco-friendly method to suppress the weed population and effective management in weed control.

\section{Introduction}

Trees perpetually contribute to the sustainability of food production and livelihood (Reed et al., 2017). With the increasing recognition of agroforestry as alternative land use, many scientists have focused their attention on trees. Most of these tree species are exotics and highly suitable due to their easy mode of maintenance, high 
environment adaptations, fast growth, and high productive capacity (Gattoo, 2013). Among them, Eucalyptus has succeeded as a preferred species for agroforestry and farm forestry interventions throughout the country (Sachan 2006). Eucalyptus species (E. citriodora), Tasmanian blue gum (E. globulus), blue mallee (E. polybractea), and River red gum (E. camaldulensis) consists of tall, magnificent and evergreen trees with fragrant foliage rich in oil glands (Brooker and Kleinig 2006). Nevertheless, there is a continuing controversy about the ecological functions of the Eucalyptus tree. Its allelopathic effect on understory crops has also been reported by some studies (Sasikumar et al., 2002; Kong et al., 2019; Thiebout et al., 2019). However, this effect may be exploited as an effective means to manage weeds, especially under agroforestry mode.

A weed possesses various toxicological effects on the ecosystem. Worldwide, a large amount of money is spent every year to control them. Weed infestation in agricultural fields results in huge economic losses and low-quality crop yields. In India, the total actual economic loss due to weed infestation was USD 11 billion in 10 major crops (Gharde et al., 2018). A successful establishment of a weed in an ecosystem is attributed to its rapid growth rate, long-lived seeds, high reproductive potential, longer seed dispersal rate, competitiveness, and allelopathy (Gattoo et al., 2013). Three Allelopathy ways have been mentioned for weed management, Firstly, by selecting desired crop variety, rotational use of allelopathy species, and lastly use of allelochemicals as natural herbicides (Rice, 1995; Farooq, 2020). The control of weeds can be achieved through several means, unfortunately, the use of synthetic herbicides may affect the environment and human health, and is also leading to increasing resistance among many weed species. Globally, 2 million ton pesticides are being utilized and out of which herbicides contribution is $47.5 \%$ (Sharma et al., 2019). Globally, there is a continuous up-gradation in herbicide-resistant weed species approx 262 thus, profusely expanded the use of more herbicides (Comont et al., 2019; Heap 2020). Therefore, efforts to develop alternative means of weed control, which are not only eco-friendly but also cost-effective and bio efficacious are needed (Bhadoria 2010; Gnanavel 2015). In this direction, efforts to utilize allelopathy which is generally associated with the interaction between living plants, a significant role in plant-plant interaction, and natural plant products for effective weed management are being made (Singh et al., 2003; Amist 2019). Growing environmental and public health concerns from the use of agricultural chemicals (pesticides) in agriculture have stimulated interest in the search for new and environmentally safe technologies for effective inhibition of weeds (Rice 1994; ElMetwally and El-Rokiek, 2019).

Allelopathy may be a successful tool to manage weed infestation in agricultural production if it can be exploited appropriately in a rotational cropping system (Khanh et al., 2005). However, in the case of trees, it is difficult to apply the concept of rotation; therefore, enhancing weed suppression by trees itself through litterfall and isolation of natural plant products may be among the most feasible means of controlling weeds. The isolation and identification of allelochemicals responsible for weed suppression by trees may help understand the chemical interactions of trees and other plant communities.

Not all plants have allelopathic tendencies; a lot of tree-crop combinations are being practiced in the agroforestry system to form the suitable match. Many studies reported 
negative interactions, thus, reduced growth and yield of the crop under trees due to phytotoxic interference viz., allelopathy (Singh 2001a). On the contrary, allelopathy could be beneficial in weed species by reducing weed emergence. The allelopathic effects of Eucalyptus have deleterious effects on another plant species by releasing Phenolic acids and volatile oils from the leaves, bark, and roots (Sasikumar et al., 2001; El-Khawas and Shehata, 2005, Jawahar 2013; Puig 2018). Eucalyptus reported a combination of both positive and negative interactions on various crops and weed species (Schumann et al., 1995; Romagni et al., 2000; Sasikumar et al., 2001). Allelopathic potential of Eucalyptus has been reported by few studies on chlorophyll content, respiratory activity, seedling length, and germination (Kohli et al., 1998; Singh et al., 2005; Hegab et al., 2016; Wu et al., 2019). Similarly, other species also documented deteriorating effects of Eucalyptus species on Phalaris minor, Cassia occidentalis, Echinochloa crusgalli, Amaranthus hybridus, Portulaca oleracea, Cyperus rotundus, and Cynodon dactylon, Asphodelus tenuifolius, Brassica campestris, Triticum aestivum, Physalis hederifolia and Ipomoea species (Batish et al., 2004; Batish et al., 2007; Khan and Marwat et al., 2005; Babu and Kandasamy. 2008; Verdeguer et al., 2009; Wu et al., 2019). Besides Eucalyptus, species such as rice, sunflower, and sorghum were also studied for the inhibitory effect on Parthenium (Javaid et al., 2006). Although the research on allelopathy in cropping systems has increased in the last two decades, the allelopathic influences of the comparative analysis of Eucalyptus species on weeds have been little investigated. The present investigation "Bioherbicidal potential of Eucalyptus aqueous leaf extract (ALE) and leaf oil (LO) on Parthenium hysterophirum" was carried out with the objectives to assess the inhibitory effect of ALE and LO of Eucalyptus species on germination characteristics and growth performance of weed Parthenium hysterophorus.

\section{Materials and Methods}

\section{Site description}

The experiment was conducted during Rabi season in the laboratory conditions at Dr.Yashwant Singh Parmar University of Horticulture and Forestry, Himachal Pradesh (India). The center is located at $29^{\circ}$ north latitude $30.92^{0} \mathrm{~N} 77.12^{0} \mathrm{E}$ longitudes and altitude of 1256.40 meters above the mean sea level, which lies in the foothills of the Shivalik range of the Himalayas in the narrow strips.

\section{Plant material}

25-year-old Eucalyptus species, Eucalyptus citriodora (lemon-scented gum) (E1), Eucalyptus camaldulensis (River Red Gum) (E2) and Eucalyptus tereticornis (Forest Red Gum) (E3) were used as the donor plant, collected from Dr.Y.S.P.University of Horticulture and Forestry, Nauni, Solan (Himachal Pradesh). The seeds of $P$. hyterophorus were procured from Norman E. Borlaug Crop Research Center, G. B. Pant University of Agriculture \& Technology, Pantnagar. The seeds obtained were off last season in January, and the viability test was conducted during the experiment. The laboratory experiment was laid out in a factorial completely randomized design with three replications.

\section{Aqueous extract preparation}

To evaluate the effect of a water-soluble extract of the Eucalyptus genus, fresh leaves of three Eucalyptus species were collected and washed thoroughly with tap water followed by distilled water to remove dust. After blotting dry with filter paper (Whatman 
No. 1) $250 \mathrm{~g}$ of fresh leaves was ground in $500 \mathrm{ml}$ of distilled water in a household blender for 10 minutes. The extract was then filtered through two layers of Whatman No. 1 filter paper and residue was washed thoroughly 2 to 3 times and made it up to 1 liter by the addition of distilled water, thus the stock solution of $100 \%$ aqueous extract was prepared. The stock solution was then stored in a refrigerator in a dark place in conical flasks until required. The extract was further diluted to $10,25,50$, and $75 \%$ extract concentration.

\section{Extraction of volatile oil}

Oil was extracted by hydrodistillation using Clevenger's apparatus. Weighed fresh leaves of three Eucalyptus species viz.; E. citriodora, E. camaldulensis and E. tereticornis were collected. Freshly collected leaves of Eucalyptus species were weighed to 250 grams, chopped into pieces, and mixed with llitre normal water at room temperature (210C) in a round bottom flask (2 liters) and boiled for 4 hours at 95 to $1000 \mathrm{C}$ temperature. The oil was collected from the nozzle of the condenser, stored in glass vials and dried under sodium sulfate, and stored at 40C in the freezer for bioassay studies. The oil was diluted to $0.25,0.5,1.0,2.0$, and $5.0 \mathrm{ppm}$ at the time of application to seeds.

\section{Measurements}

\section{Seed germination test}

Healthy and uniform size seeds of all test plants were selected and soaked in distilled water for 12 to 48 hours and treated with a small amount of thiram (quantity). The bottom of $15 \mathrm{~cm}$ diameter Petri dishes was covered with Whatman No. 1 filter paper. To test the inhibitory effect of leaf aqueous extract and oil, $10 \mathrm{ml}$ of different concentrations and distilled water in control were loaded on the inner side of the cover of the Petri dish. Twenty seeds of each test species were evenly placed in Petri dishes on a filter paper. Later on, two ml of extracts were subsequently added daily to keep the filter paper moistened. After spacing the seeds equally on the base, the Petri dish was immediately sealed with tape. Control was kept with distilled water. For each concentration, three replicates were maintained. All the Petri dishes were kept in an incubator at $200 \mathrm{C}$ temperatures in dark.

\section{Germination per cent}

The number of seeds germinated was counted daily up to the final day I. e.14 days for weed species or up to the time when the majority of seeds emerged and the normal seedlings were checked out. The seedlings with well developed, complete, proportionate and healthy essential structures were considered as normal seedlings and the seedlings with any one of the essential structures missing or badly damaged, weak or unbalanced development of essential structures and with any one of the essential structures showing diseased or decayed symptoms were counted as abnormal seedlings. Germination was observed daily according to the Association of Official Seed Analysts method (AOSA 1998). A seed was considered germinated when it had attained a $2 \mathrm{~mm}$ radicle length. Based on the above information seedlings were evaluated on the final day (disturbed or abnormal seeds were not counted) according to standard germination procedure and it was calculated as:

Germination Percentage $=\frac{\text { No. of seeds produced normal seedlings }}{\text { No. of seeds set for germination }} \times 100$

\section{Speed of germination}

The number of seedlings emerging was counted daily from the day of planting the 
seeds in the medium till the time germination is completed. Speed of germination also known as germination index was calculated with the method suggested by Association of Official Seed Analysts (AOSA 1983) using the following formula

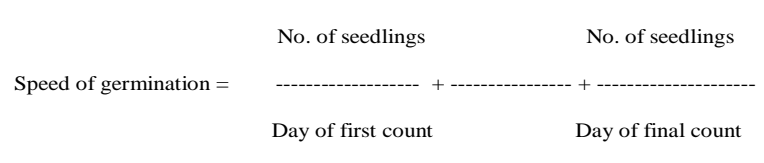

\section{Shoot/root/seedling length}

The shoot and root length of seedlings were measured with the help of scale from tip to the base of the shoot and root at the final day after placing seeds in Petri dishes. The average shoot and root length were worked out by dividing total shoot and length $(\mathrm{cm})$ with the number of seedlings. It was expressed in $\mathrm{cm}$ per seedling. The seedling length of the test plant species was obtained by the summation of root length and shoot length of seedlings and it was expressed in centimeters. It is the mean seedling length.

\section{Seed vigour index}

Vigour index is the product of the germination percentage and mean seedling length and informed about the health of the plant. It is calculated by using the formula-

Vigour index $=$ Germination percent $\mathrm{x}$ Mean seedling length.

\section{Phytotoxicity per cent}

The phytotoxic symptoms include shortened roots; discolored root tips; root raised from the paper; inhibition of root hairs development and root hairs bunched. The symptoms are more pronounced at an early stage of root growth. The phytotoxic symptoms are also evident in the plumular areas in the form of thickened or flattened plumules or, coleoptiles. The phytotoxicity can be calculated as per the formula evolved by Surendra and Pota (1978).

Phytotoxicity $\%=\frac{\text { Seedlinglength of control }- \text { Seedlinglength of treatme }}{}$ inglength of control

\section{Statistical Analysis}

The experimental data obtained were subjected to statistical analysis one-way analysis of variance (ANOVA) using SPSS statistics 16 software, Tukey's post hoc test was used when variances remained homogeneous (Levene's test) and T3 Dunnett's post hoc test was employed if not, assuming equal variances. Differences were considered to be significant at $p \leq 0.05$.

\section{Results and Discussion}

\section{Germination percent}

Different Eucalyptus species respond differently and significantly influenced the germination percent in both aqueous leaf extract (ALE) and leaf oil (LO) concentrations (Fig. 1). The study reported germination percent of Parthenium hysterophorus with maximum inhibitory effect of $\sim 16.6$ and 18.9 (E. citriodora; E1) followed by $\sim 21.3$ and 30.1 (E. camaldulensis; E2) and 24.8 and 33.4 (E. tereticornis; E3) in both ALE and LO concentrations respectively (Fig. 1).

Further, bioassay of E. citriodora significantly impedes the germination of weed species. The inhibition effect increased with the increasing concentrations in both ALE and LO (Fig. 2). The germination percent was significantly and progressively reduced by maximum reduction in aqueous leaf extract and leaf oil concentration up to $100 \%$ and 5 ppm respectively when compared to counterparts i.e. control (Fig. 2). 


\section{Speed of germination}

There was a profound reduction in the speed of germination with each Eucalyptus species of ALE and LO (Fig. 1). Significantly higher reduction in speed of germination was recorded in species E1 $\sim 2.8$ (LO) when compared to $\sim 4.8$ (ALE). Whereas, the accelerated speed was recorded in E3 by $\sim 6.2$ (LO) on comparison to $~ 5.5$ (ALE) (Fig. 1). Subsequently, each increment in the concentration of ALE and LO of Eucalyptus citridora decreased the speed of germination of Parthenium hysterophorus significantly (Fig. 3). In aqueous extract, maximum speed of germination was obtained at control, while $100 \%$ leads to zero speed i.e. 100 percent inhibition (Fig. 3). Whereas, in LO concentrations, the maximum inhibition was recorded at $5.0 \mathrm{ppm}$ (Fig. 3).

\section{Shoot and Root length}

The inhibition potential of Eucalyptus species in shoots and root length of Parthenium hysterophorus was ranked as E. citriodora followed by $E$. camaldulensis and $E$. tereticornis (Table 1; A). Different concentrations of ALE and LO significantly suppressed the growth rate and the magnitude of inhibition was increased successively (Table 1; B). The application of ALE results maximum inhibition at $100 \%$ with no root emergence, whereas $75 \%$ has inhibition of $\sim 0.9$ and $\sim 0.24$, in shoot and root part successively.

Similarly, LO concentration enhanced maximum suppression at 5 ppm concentrations with $\sim 0.3$ (Shoot) and $\sim 0.17$ (root) when compared to control $\sim 2.5$ (Shoot) and $\sim 2.2$ (root) (Table 1; B). Maximum deterioration in total seedling length was observed by the application of E. citriodora aqueous leaf extract followed by $E$. camaldulensis. Lowest inhibition in the seedling length was observed in $E$. tereticornis. Decreasing trend in seedling length was found with increasing concentration from 0 to $100 \%$ aqueous leaf extract and $5 \mathrm{ppm}$ concentration of leaf oil. Interaction effect revealed the complete inhibition of seedling length of $P$. hysterophorus at $100 \%$ aqueous leaf extract concentration in all the Eucalyptus species (Table 1; B).

\section{Seed vigour index}

Seed vigour was significantly influenced by all Eucalyptus species as well as ALE and LO concentrations (Fig. 1 and 2). The seed vigour of Parthenium hysterophorus was significantly reduced to minimum in $E$. citriodora as compared to E. camaldulensis and E. tereticornis (Fig. 1). The seed vigour was significantly reduced with increase in concentration of aqueous leaf extract from 0 to $100 \%$ (Fig. 3). At $75 \%$ concentration up to 96 percent reduction was observed as compared to control. The increase concentration of leaf oil from 0 to $5 \mathrm{ppm}$ significantly decreased seed vigour. From 0.25 to $5 \mathrm{ppm}$ concentration the vigour was continuously reduced and reached to its minimum value at $5 \mathrm{ppm}$ concentrations (Fig. $3)$.

\section{Phytotoxicity per cent}

The phytotoxicity per cent was significantly influenced by each Eucalyptus species concentrations of aqueous leaf extract and leaf oil as represented (Fig. 1). Oil extract of E. citriodora has been proven more toxic than aqueous extract. Significantly higher phytotoxicity percent $\sim 54$ (LE); $\sim 60$ (LO) was recorded in E. citriodora, while minimum phytotoxicity percent $\sim 39.7$ (LE); 44 (LO) was recorded under E. tereticornis (Fig. 1). 
Table.1 The response of Aqueous leaf extract (ALE) and Leaf oil (LO) of Eucalyptus species

(A) and E. citridora concentrations (B) on the average initial growth of $P$. hysterophorus

\begin{tabular}{|l|l|c|c|c|c|c|c|}
\hline A & & \multicolumn{2}{|c|}{ Aqueous leaf extract (ALE) } & \multicolumn{3}{|c|}{ Leaf oil (LO) } \\
\hline S. No. & Eucalyptus spp. & $\begin{array}{c}\text { Root length } \\
\text { (cm) }\end{array}$ & $\begin{array}{c}\text { Shoot } \\
\text { length } \\
\text { (cm) }\end{array}$ & $\begin{array}{c}\text { Total } \\
\text { seedling } \\
\text { length }(\mathbf{c m})\end{array}$ & $\begin{array}{c}\text { Root } \\
\text { length }\end{array}$ & $\begin{array}{c}\text { Shoot } \\
\text { length }\end{array}$ & $\begin{array}{c}\text { Total } \\
\text { seedling } \\
\text { length }\end{array}$ \\
\hline 1. & E. camaldulensis & 1.03 & 1.6 & 2.7 & 1.1 & 1.1 & 2.2 \\
\hline $\mathbf{2 .}$ & E. tereticornis & 1.08 & 1.9 & 3.0 & 1.3 & 1.4 & 2.7 \\
\hline 3. & E. citriodora & 0.97 & 1.30 & 2.3 & 0.83 & 0.89 & 1.7 \\
\hline
\end{tabular}

\begin{tabular}{|l|c|c|c|c|c|c|c|c|}
\hline B & \multicolumn{3}{|c|}{ Aqueous leaf extract (ALE) } & \multicolumn{4}{|c|}{ Leaf oil (LO) } \\
\hline $\begin{array}{l}\text { S. } \\
\text { No. }\end{array}$ & $\begin{array}{c}\text { Concentrations } \\
(\mathbf{\%})\end{array}$ & $\begin{array}{c}\text { Root } \\
\text { length }\end{array}$ & $\begin{array}{c}\text { Shoot } \\
\text { length }\end{array}$ & $\begin{array}{c}\text { Total } \\
\text { seedling } \\
\text { length }\end{array}$ & $\begin{array}{c}\text { Concentrations } \\
\text { (ppm) }\end{array}$ & $\begin{array}{c}\text { Root } \\
\text { length }\end{array}$ & $\begin{array}{c}\text { Shoot } \\
\text { length }\end{array}$ & $\begin{array}{c}\text { Total } \\
\text { seedling } \\
\text { length }\end{array}$ \\
\hline $\mathbf{1 .}$ & Control & 2.2 & 2.8 & 5.0 & Control & 2.2 & 2.5 & 4.7 \\
\hline $\mathbf{2 .}$ & $\mathbf{1 0}$ & 1.54 & 2.4 & 4.0 & $\mathbf{0 . 2 5}$ & 1.5 & 1.6 & 3.1 \\
\hline $\mathbf{3 .}$ & $\mathbf{2 5}$ & 1.22 & 2.0 & 3.2 & $\mathbf{0 . 5 0}$ & 1.1 & 1.3 & 2.4 \\
\hline $\mathbf{4 .}$ & $\mathbf{5 0}$ & 1.01 & 1.5 & 2.6 & $\mathbf{1 . 0 0}$ & 0.5 & 1 & 1.5 \\
\hline $\mathbf{5 .}$ & $\mathbf{7 5}$ & 0.24 & 0.9 & 1.2 & $\mathbf{2 . 0 0}$ & 0.4 & 0.5 & 0.9 \\
\hline $\mathbf{6 .}$ & $\mathbf{1 0 0}$ & 0.0 & 0.0 & 0.0 & $\mathbf{5 . 0 0}$ & 0.17 & 0.3 & 0.47 \\
\hline
\end{tabular}

Fig.1 Effect of leaf oil and aqueous leaf extract of three exotic Eucalyptus species (E. citriodora (E1), E. camaldulensis (E2) and E. tereticornis (E3) on A- Germination Percentage (GP); BSpeed of Germination (SG); C- Seed vigor (SV); D-Phytotoxicity Percentage (PP) of $P$. hysterophorus seeds
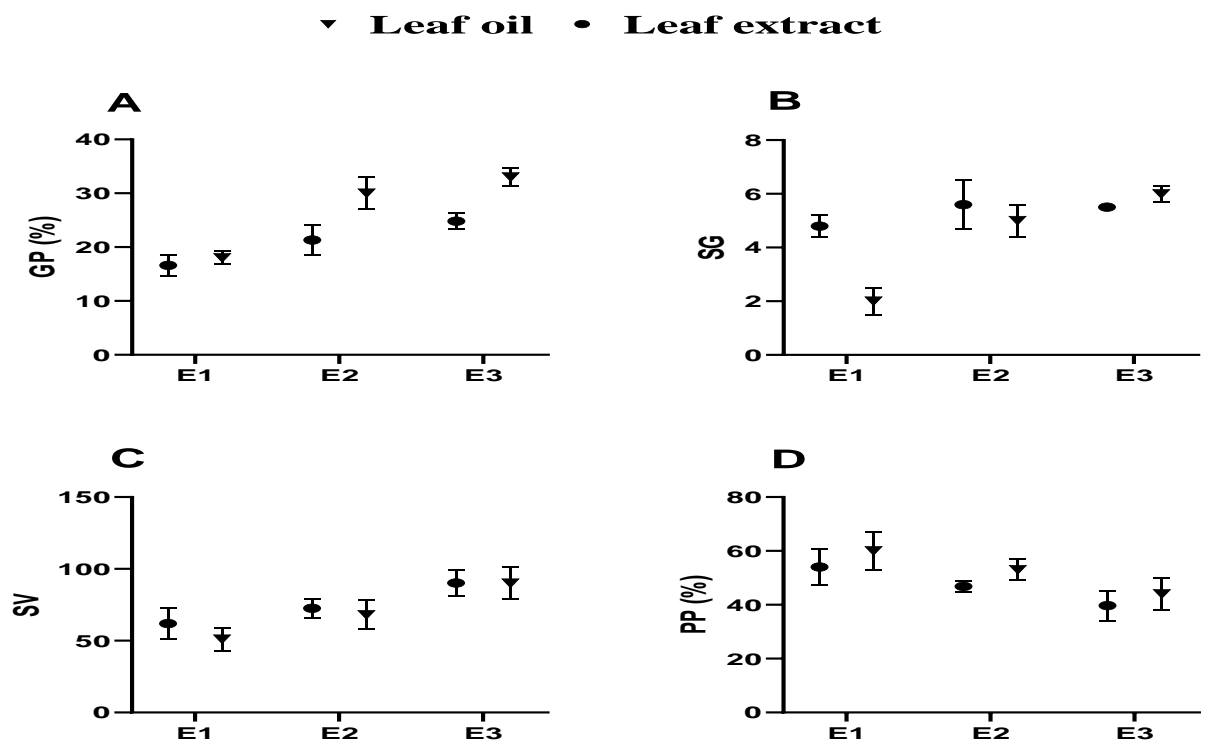
Fig.2 A) Germination percent B) Phytotoxicity percent of $P$. hysterophorus seeds at different $E$. citridora concentrations of aqueous leaf extract and leaf oil
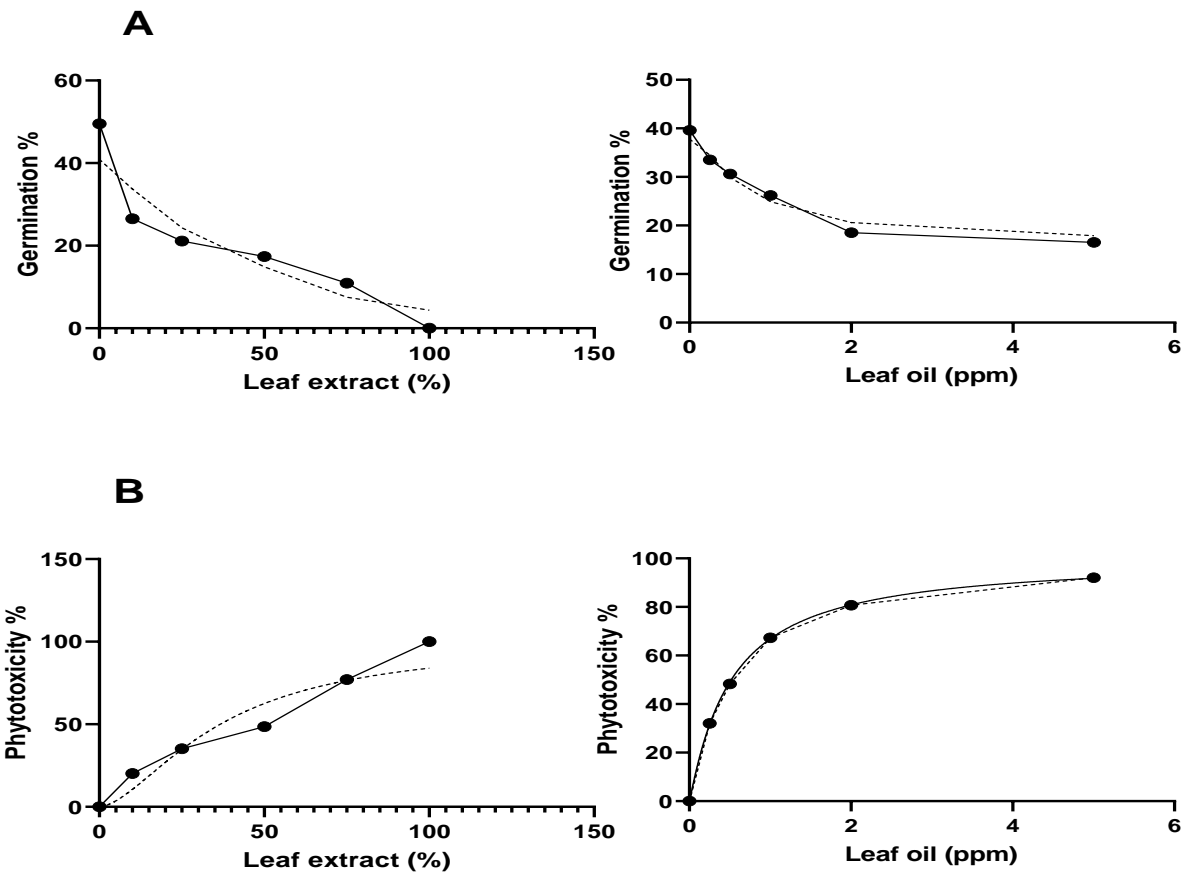

Fig.3 Effect of different concentrations of leaf oil and aqueous leaf extract of E. citriodora on Speed of Germination and Seed vigor of $P$. hysterophorus seeds
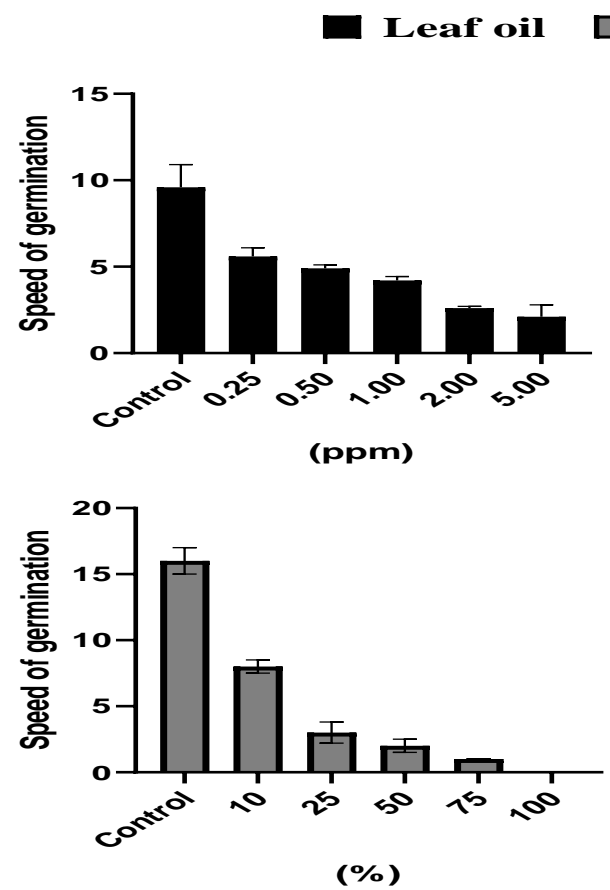

Leaf extract
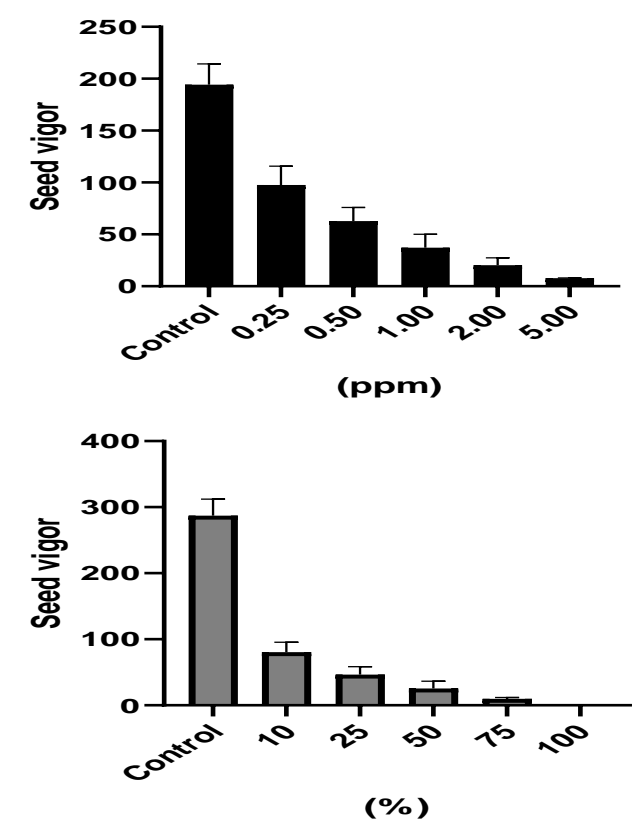
The increasing trend in phytotoxicity per cent was observed with every increase in the concentration of LE and LO from control to $100 \%$ and 5 ppm respectively (Fig. 2). Control (distilled water) did not have any phytotoxic effect on Parthenium hysterophorus, whereas, successive increase in the concentration of aqueous extract from 10 to $100 \%$ phytotoxicity percent enhanced. Significantly highest phytotoxicity 100 percent was recorded at $100 \%$ aqueous leaf extract concentration against $P$. hysterophorus. Application of distilled water did not cause any phytotoxic effect on Parthenium but with an increase in the concentration of leaf oil from 0.25 to $5 \mathrm{ppm}$ enhanced the phytotoxicity level. Significantly highest phytotoxicity 100 percent was recorded at 5 ppm concentrations against Parthenium weed (Fig. 2).

Allelochemicals also as nature's herbicides have several benefits over synthetic compounds. Natural compounds may have a novel structure due to the diversity of molecular structure. Natural products relatively have a short half-life and are biodegradable therefore, considered safe from environmental toxicology standpoint (Duke et al., 2002). Among natural plant products, volatile essential oils and their constituents have attracted much attention because of their phytotoxicity (also providing allelopathic property) and relatively quicker degradation in the environment (Muller 1965; Kohli and Singh 1991; Romagni et al., 2000; Singh et al., 2002; Tworkoski, 2002; Ibanez and Blazquez 2018). Extensive commercial exploitation of natural derivatives has been reported in order to reduce the use synthetic pesticides (Masum et al., 2016; Trezzi et al., 2016; El-Mergawi and Al-Humaid 2019). Allelopathic agents influenced plant growth by affecting various physiological processes such as cell division and cell elongation, phytohormone induced growth, membrane permeability, mineral uptake, stomatal uptake, photosynthesis and respiration (Rice 1994).

The allelochemicals specifically target the enzymes of plant metabolism and suppressed the growth and development mechanism. For instance, Terpenes present in the leaf part inhibit the germination process of seeds (Padhy 2000). The essential oil from $E$. citriodora was more toxic than E. tereticornis and it was attributed to the variability in their chemical constitution. A similar study was reported by Chaturvedi et al., (2012) concluded that Eucalyptus citridora is most toxic as compared to other Eucalyptus species examined on target weed species. Aqueous extract and oil concentrations proved highly effective against weed species where different employed treatments reduced the final germination by $100 \%$ (Isik et al., 2016; Mekky et al., 2019; Scavo et al., 2019). Subsequently, Shafique et al., (2005) found that the leaf extract of $M$. indica was highly suppressive against $P$. hysterophorus. Besides these, Glycine max and Zea mays also reduced the germination and seedling vigor in weeds Bidens and Eleusine species (Dhungana et al., 2019).

Reduction in seedling growth may probably be due to the loss/ disruption of mitotic (Romagni et al., 2000). The exact mechanism, by which seedlings length is affected by Eucalyptus oil, could be due to the inhibition of mitosis in the growing cells, as essential oils are reported to inhibit sprout growth in potato by killing meristematic cells. The seedling length of parthenium was reduced by $56 \%$ due to Eucalyptus oil (Singh et al., 2005). Kohli et al., (1998) have mentioned that the oil present in the leaves coins with the leaf diffusibility, rate, and stomatal aperture and eventually leads to wilting of the plant species, thereby suppressed the growth. This study has also been supported by reporting the n-hexane, acetone, and water-soluble 
fractions inhibition shoot growth of lettuce with an increase in the concentration of the extracts (Ashrafi et al., 2008). The Root length of weed species such as Phalaris minor, $P$. hysterophorus has reported to reduced by the application of E. citriodora, $E$. globules extracts, and Alstonia species (Kohli et al., 1991; Javaid et al., 2006).

Possessing great weed-suppressing ability, other studies have also been reported in essential oils of E citridora phytotoxicity on weed species such as Portulaca oleracea, Lolium multiflorum, Amaranthus viridis and Echinochloa crusgalli (Ibanez and Blazquez 2019). Besides this, other Eucalyptus species; E. camaldulensis and E. globulus have also reported reducing the germination efficiency and phytotoxic effects on Solanum lycopersicum, Lactuca sativa and Agrostis stolonifera (Fikreyesus, 2011; Puij, 2018).

In conclusion the $E$ citridora oil has maximum inhibition impact with high phytotoxicity percentage than aqueous extract on weed $P$. hysterophorus and might be used as a potential species in weed management and as an alternative in weed control. There are indications of a possible role played by allelopathy in weed suppression by Eucalyptus; most of these studies have focused on the physical suppression of weeds. Thus, there is a need to critically analyze the differential response (if any) of allelochemicals secreted by Eucalyptus on weed species.

\section{Acknowledgments}

We thank the directors of Forest research Institute, Dehradun and Dr. Y.S.P.U.H.F Nauni, for allowing us to work and continuous support. Also, thankful to the Director G.B. Pant institute for providing seed material. This research did not receive any specific grant from funding agencies in the public, commercial, or not-for-profit sectors.

\section{References}

AOSA. 1983. Seed vigor testing handbook: Contribution no. 32 to handbook on seed testing. Association of Official Seed Analysis, Springfield, IL., USA, pp: $1-93$

AOSA (Association of Official Seed Analysts). 1998. Rules for seed testing. AOSA, Beltsville, MD. Amist N, Li ZR, Bai LY. 2019. Allelopathy in sustainable weeds management. Allelopathy J. 48: 109-138

Ashrafi ZY, Rahanavard A, Sadeghi S, Hassan MA, Mashhadi HR. 2008. Study of the Allelopathic potential of extracts of Azadirachta Indica (neem). J. Biol. Sci. 8: 57-61

Babu RC, Kanadasamy OS. 2008. Allelopathic effect of Eucalyptus globules Labill. on Cyperus rotundus L. and Cynodon dactylon L. Pers. J. Agron. Crop Sci. 179:123-126

Batish D, Setia N, Singh HP, Kohli RK. 2004. Phytotoxicity of lemon-scented eucalypt oil and its potential use as a bioherbicide. Crop Prot. 23: 1209-1214

Batish DR, Singh HP, Setia N, Kohli RK, Kaur S, Yadav, SS. 2007. Alternative control of littleseed canary grass using eucalypt oil. Agron. Sustain. Dev. 27: 171-177

Bhadoria PBS. 2011. Allelopathy: a natural way towards weed management. Am. J. Exp. Agric. 1:7-20

Brooker MIH, Kleinig DA. 2006. Field Guide to Eucalyptus. Ed 3, Vol 1. Bloomings Books, Melbourne, p 356

Chaturvedi SJ, Pandey VC, Dhyani SK, Guru, Kaushal R. 2012. Phytotoxic potential of Eucalyptus leaf essential oil to control Parthenium hysterophorus L. Allelopathy J. 29: 315-324 Comont BD, Hicks H, Crook L, Hull R, 
Cocciantelli E, Hadfield J, Childs D, Freckleton R, Neve P. 2019. Evolutionary epidemiology predicts the emergence of glyphosate resistance in a major agricultural weed. New Phytol. 223: $1584-1594$

Dhungana SK, Kim I, Adhikari B, Kim J, Shin D. 2019. Reduced germination and seedling vigor of weeds with root extracts of Maize and Soybean, and the mechanism defined as Allelopathic. J. Crop Sci. Biotechnol. 22: 11-16

Duke SO, Dayan FE, Rimando RM, Scharder KK, Aliotta G, Oliva A, Romagni JG. 2002. Chemicals from nature for weed management. Weed Sci. 50: 138-151

El-khawas SA, Shehata MM. 2005. The allelopathic potentialities of Acacia nilotica and Eucalyptus rostata on monocot (Zea mays) and dicot (Phaseolus vulgaris L.) plants. Biotechnol. 4: 23-34

El-Mergawi RA, Al-Humaid AI. 2019. Searching for natural herbicides in methanol extracts of eight plant species. Bull. Natl. Res. Cent. 43: 1-6

El-Metwally IM, El-Rokiek KG. 2019. Eucalyptus citriodora leaf extract as a source of allelochemicals for weed control in pea fields compared with some chemical herbicides. J. Plant Protect. Res. 59: 392-399

Farooq N, Abbas T, Tanveer A, Jabran K. 2020. Allelopathy for Weed Management. In: JM Mérillon, K Ramawat, eds, Co-Evolution of Secondary Metabolites. Reference Series in Phytochemistry. Springer, Cham, Switzerland, pp 505-519

Fikreyesus S, Kebebew Z, Nebiyu A, Zeleke N, Bogale S. 2011. Allelopathic Effects of Eucalyptus camaldulensis dehnh. on germination and growth of tomato. American-Eurasian J. Agr. Environ. 11: 600-608

Gattoo AA. 2013. An overview of exotic forestry in India. Ann. Agri. Bio. Res. 18:55-61

Gharde Y, Singh PK, Dubey RP, Gupta PK. 2018. Assessment of yield and economic losses in agriculture due to weeds in India. Crop Prot. 107: 12-18

Gnanavel I. 2015. Eco-Friendly Weed Control Options for Sustainable Agriculture. Science International. 3: 37-47

Heap I. The International Herbicide-Resistant Weed Database. [www document] URL http:// www.weedscience.org / [accessed May 25 2020]

Hegab MM, Gabr MA, Al-Wakeel SAM, Hamed BA. 2016. Allelopathic Potential of Eucalyptus rostrata Leaf Residue on Some Metabolic Activities of Zea mays L. Univers. J. Plant Sci. 4: 11-21

Ibanez MD, Blazquez MA. 2018. Phytotoxicity of Essential Oils on Selected Weeds: Potential Hazard on Food Crops. Plants 7: 79-94

Isik D, Mennan H, Cam M, Tursun N, Arslan M. 2016. Allelopathic potential of some essential oil bearing plant extracts on common lambsquarters (Chenopodium album L.). Rev. Chim-Bucharest 67: 455-459

Javaid A, Shafique S, Shafique S. 2006. Herbicidal potential of aqueous leaf extract of allelopathic trees against Phalaris minor. Pak. J. Weed Sci. Res. 12: 339-346

Jawahar S, Lakshmi AV, Kalaiyarasan C, Suseendran K. 2013. Herbicidal efficacy of Eucalyptus oil in parthenium (Parthenium hysterophorus L.) control. Life Sci. Leafl. 3: 79-88

Khan MA, Marwat KB, Hussan Z. 2004. Allelopathic potential of some multipurpose tree species on the wheat and some of its associated weeds. Int. J. Biol. Biot. 1: 275-278

Khanh TD, Xuan TD, Chung IM. 2007. Rice allelopathy and the possibility for weed management. Ann. Appl. Biol. 151: 
325-339

Kohli RK, Batish D, Singh HP. 1998. Eucalyptus oil for the control of Parthenium hysterophorus L. Crop Prot. 17: 119-122

Kohli RK, Singh D. 1991. Allelopathic impact of volatile components from Eucalyptus on crop plants. Biol. Plantarum 33: 475-483

Kong CH, Xuan TD, Khanh TD, Tran HD, Trung NT. 2019. Allelochemicals and Signaling Chemicals in Plants. Molecules 24: 2737 doi: 10.3390/molecules24152737

Masum SM, Hossain MA, Akamine H, Sakagami JI, Bhowmik PC. 2016. Allelopathic potential of indigenous Bangladeshi rice varieties. Weed. Biol. Manag. 16:119-131

Mekky MS, Hassanien AMA, Kamel EM, Ismail AEA. 2019. Allelopathic effect of Ocimum basilicum L. extracts on weeds and some crops and its possible use as new crude bio-herbicide. Ann. Agr. Sci. 64: 211-221

Muller WH. 1965. Volatile materials produced by Salvia leucophylla: effect on seedling growth and soil bacteria. Bull. Torr. Bot. Club. 92: 38-45

Padhy BT, Patnaik PK, Tripathy AK. 2000. Allelopathic potential of Eucalyptus leaf litter leachates on germination and seedling growth of fingermillet. Allelopathy J. 7: 69-78

Puig CG, Reigosa MJ, Valentão P, Andrade PB, Pedrol N. 2018. Unravelling the bioherbicide potential of Eucalyptus globulus Labill: Biochemistry and effects of its aqueous extract. PLoS One 13: e0192872

Reed J, Vianen J, Foli S, Clendenning J, Yang K, MacDonald M, Petrokofsky G, Padoch C, Sunderland T. 2017. Trees for life: The ecosystem service contribution of trees to food production and livelihoods in the tropics. Forest
Policy Econ. 84: 62-71

Rice EL. 1994. Overview of Allelopathy, In SS Narwal, P Tauro, eds, Allelopathy in Agriculture and Forestry. Scientific Publishers, Jodhpur, India, pp 1-21

Rice EL. 1995. Biological Control of Weeds and Plant Diseases: Advances in Applied Allelopathy. University of Oklahoma Press, Norman, Okla, 439 pp

Romagni JG, Allen SN, Dayan FE. 2000. Allelopathic effects of volatile cineoles on two weedy plant species. J. Chem. Ecol. 26: 303-313

Sachan MS. 2006. Structure and Functioning of Traditional Agroforestry Systems Along an Altitudinal Gradient in Garhwal Himalaya. Ph. D. thesis. H.N.B. Garhwal University, Srinagar Garhwal, Uttranchal, India

Sasikumar K, Vijayalkshmi C, Prathiban KT. 2001. Allelopathic effect of 4 Eucalyptus species on Red gram (Cajanus cajan L.) J. Trop. Agr. 39: 134-138

Sasikumar K, Vijayalakshmi C, Parthiban KT. 2002. Allelopathic effects of Eucalyptus on blackgram (Phaseolus mungo L.) Allelopathy J. 9: 205-214

Scavo A, Pandino G, Restuccia A, Lombardo S, Pesce GR, Mauromicale G. 2019. Allelopathic potential of leaf aqueous extracts from Cynara cardunculus L. on the seedling growth of two cosmopolitan weed species. Ital. J. Agron. 14: 78-83

Schumann AW, Little KM, Eccles NS. 1995. Suppression of seed germination \& early seedling growth by plantation harvest residues. South Afr. J. Plant Soil 12: $170-172$

Shafique S, Bajwa R, Javaid A. 2005. Biological control of Parthenium IV. suppressive ability of aqueous leaf extracts of some allelopathic trees against germination and early seedling growth of Parthenium hysterophorus. 
Pak. J. Weed Sci. Res. 11: 75-79

Singh H, Kohli R, Batish D. 2001. Allelopathic interference of Populus deltoides with some winter season crops. Agronomie 21: 139-146

Singh HP, Batish DR, Kohli RK. 2001. Allelopathic effect of two volatile monoterpines against bill goat weed. Crop Prot. 21: 347-350

Singh HP, Batish D, Kohli RK. 2003. Allelopathic interactions and allelochemicals: new possibilities for sustainable weed management. Crit. Rev. Plant. Sci. 22: 239-311

Singh HP, Batish DR, Kaur S, Ramezani H, Kohli RK. 2002. Comparative phytotoxicity of four monoterpenes against Cassia occidentalis. Ann. Appl. Biol. 141: 111-116

Singh HP, Batish DR, Setia N, Kohli RK. 2005. Herbicidal activity of volatile oils from Eucalyptus citriodora against Parthenium hysterophorus. Ann. Appl. Biol. 146: 89-94

Surendra MP, Pota KB. 1978. The allelopathic potentials from root exudates from different ages of Celosia argenta L. Natl. Acad. Sci. Lett. 1: 5658

Thiebaut G, Tarayre M, Rodriguez-Perez H. 2019. Allelopathice effects of native versus Invasive Plants on one major invader. Front. Plant Sci. 10:854 doi.org/10.3389/fpls.2019.00854

Trezzi MM, Vidal RA, Balbinot AA Jr, Von Hertwig Bettencourt H, da Silva Souza Filho AP (2016) Allelopathy: driving mechanisms governing its activity in agriculture. J. Plant. Interact. 11: 53-60

Tworkoski T. 2002. Herbicide activity of essential oil. Weed Sci. 50: 425-431

Verdeguer M, Blazquez MA, Boira H. 2009. Phytotoxic effects of Lantana camara, Eucalyptus africanus essential oils in weeds of Mediterranean summer crops. Biochem. Syst. Ecol. 37: 362-369

Wu H, Lin JM, Zhang JB. 2019. Allelopathic effects of Eucalyptus salubris F. Muell. and E. Brockwayii C.A. gardner on germination and seedlings growth of prairie ground cherry (Physalis hederifolia A. Gray). Allelopathy J. 46: 109-119.

\section{How to cite this article:}

Neeraj Prajapati, Rupali Sharma and Hukum Singh. 2020. Unravelling the Bioherbicidal Potential of Eucalyptus Species Aqueous Leaf Extract and Leaf Oil on Germination and Initial Growth Performance of Weed Parthenium hysterophorus. Int.J.Curr.Microbiol.App.Sci. 9(09): 3028-3040. doi: https://doi.org/10.20546/ijcmas.2020.909.374 